\title{
CORRIGENDUM
}

\section{HEF1 is a necessary and specific downstream effector of FAK that promotes the migration of glioblastoma cells}

M Natarajan, JE Stewart Jr, EA Golemis, EN Pugacheva, K Alexandropoulos, BD Cox, W Wang, JR Grammer and CL Gladson

Oncogene (2007) 26, 7282; doi:10.1038/sj.onc.1210837

\section{Correction to:}

Oncogene (2006) 25, 1721-1732. doi:10.1038/sj.onc.1209199; published online 14 November 2005.

Since the publication of the above manuscript, the authors have identified an error in Figure $3 \mathrm{c}$. The revised version of Figure $3 \mathrm{c}$ is given here.

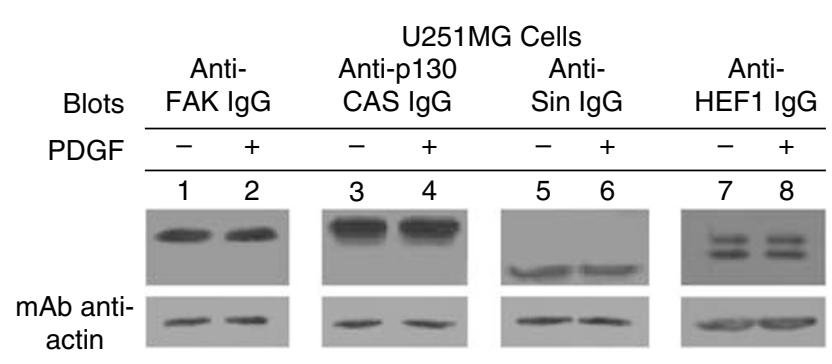

